\title{
Classification of mineral water types and comparison with drinking water
}

\section{standards}

Environmental Geology (2003) 44:554-563

DOI 10.1007/s00254-003-0791-4

N.G.F.M. van der $\mathrm{Aa}^{1}$

\begin{abstract}
In a study of 291 mineral waters from 41 different countries, 9-20\% exceeded the Dutch drinking water standards for chloride, calcium, magnesium, kalium, sodium, sulphate and fluorine. The mineral water quality cannot be qualified as bad since the standards for these compounds with the exception of fluorine, are not based on health effects but on undesirable taste effects and possible negative effects on the water supply system. For the mineral water data set the amount of dissolved compounds, hardness and chloride content appear to be the most distinctive criteria. A mineral water type classification based on these criteria will offer consumers a tool for assessing the mineral water on the basis of the chemical composition data on the bottle label. In terms of the criteria mentioned, average Dutch tap water strongly resembles the Belgian and Dutch mineral waters. This similarity does not extend to the price, since Dutch tap water is about 500 times cheaper.
\end{abstract}

Key words: mineral water, water classification, drinking/bottled water standards

\section{Introduction}

Mineral water has been gaining in popularity over the last decades. The nation-wide consumption in the Netherlands increased from 5.5 to 15.9 litres per person in the period 1980-1997 (Dutch soft drinks industry). For comparison: the consumption of coffee and milk is about 165 and 70 litres per person respectively. The Dutch mineral water market is modest as compared to other European countries like Italy, Belgium and

\footnotetext{
${ }^{1}$ Technical soil protection committee, P.O. Box 30974, 2500 GX The Hague, The Netherlands, tel: +31 703398914 e-mail: monique.vanderaa@minvrom.nl
} 
Germany. The increasing number of mineral waters for sale at supermarkets raises more questions about the differences between these mineral waters, both when compared to each other and when compared to tap water. Although the labels on most mineral water bottles indicate the chemical composition, it is often difficult and time-consuming to make a quick and clear comparison. Thus, a classification into various types of water would be useful. This paper compares describes several water classification methods in order to abstract a simple, consumer-oriented classification of the various types of mineral water. To illustrate the differences in the requirements that have to be met by mineral water and tap water, the amount of mineral waters that exceed the standards for macro-parameters and fluorine have been calculated on the basis of the WHO and Dutch drinking water standards.

\section{Differences in chemical composition of mineral waters}

To an important extent, the chemical composition of mineral waters is determined by the composition of the rock it is abstracted from. Depending on geochemical processes however, similar types of rock may lead to different types of mineral water. Subsiding sedimentary basins are normally filled with fossil marine waters of varying composition. During the fossilization of these waters, the concentration of most components increases with respect to the orignal composition. When such an area is tilted, the aquifers can become exposed at the surface, and the meteoric water may enter the system. The chemistry highly depends on the availabillity of mineralizing agents, such as temperature, $\mathrm{CO}_{2}$ concentration, redox conditions and the type of adsorption complex (Zuurdeeg and van der Weiden, 1985).

\section{EU mineral water directive}

In accordance with European legislation (directive 80/777/EEC) natural mineral water is defined as microbiologically wholesome water from an underground aquifer tapped via one or more natural or drilled wells. The only treatment allowed prior to bottling is to remove unstable components such as iron and sulphides and to (re)introduce carbon dioxide. Water from a natural source that contains few minerals is called spring water. In contrast to mineral water, which has to be bottled at the source, spring water may be transported first. Mineral water has to contain a minimum of $150 \mathrm{mg} / \mathrm{l}$ of minerals. However, local standards differ per country. The Dutch legislation does include a mineral specification. In addition to microbiological criteria, there are distinctive criteria based on the chemical composition of the water. Most countries also recognize mineral waters as having properties favourable to health: in Germany this is called Heilwasser. This is (legally) considered a medicinal 
product. In German health resorts so-called 'Heilwasser-Trinkkuren' have been used for ages. Here a therapeutic effect is assigned to certain (combinations of) dissolved compounds in mineral water.This is the only type of water that is entirely untreated. Iron and sulphur may not be filtered out and no carbon dioxide may be introduced. Clinical tests must have demonstrated that the water contributes to the prevention of certain complaints. An exception is made for water that has been known for its wholesome effect for ages.

\section{Materials and methods}

\section{Mineral water dataset}

The data set used in this investigation includes chemical analyses of macro-parameters of 291 mineral waters originating from 41 countries that can be purchased from retailers. The largest number by far originates from Europe (234). Furthermore, there are mineral waters originating from Asia (29), Africa (14), and North America (11). The continents of Australia, Middle and South America were each represented by 1 mineral water. The 5 countries represented by more than 10 different mineral waters are Germany (53), Italy (42), France (37), Spain (18) and Belgium (13). The analyses data have been copied from the bottle labels. Because the analyses data were often incomplete, only those mineral water brands were included in the dataset of which the analysis showed both calcium and chloride, and had only one of the other macro-parameters missing. The ion balance has been calculated for all analyses. In doing this, the assumption has been used that an analysis can be considered as very reliable if the error in the ion balance is less than $10 \%$. This appeared to be valid for 263 of the 302 available analyses. In a number of cases the error in the ion balance is caused by the absence in the analysis of one element (usually bicarbonate). This has been corrected for by calculating the missing element on the basis of the ion balance (the ion balance is tallied as it were). This has been done for bicarbonate (15 mineral waters), magnesium (1 mineral water) and sulphate (2 mineral waters). The eventual data set selected consisted of 291 mineral waters and includes an additional 10 mineral waters with an ion balance error of more than $10 \%$ but less than $20 \%$.

\section{Calculation of EC and TDS}

The electrical conductivity (EC) and the total amount of dissolved substances (TDS) are two important characteristic parameters for distinguishing differences among mineral waters. However, these two parameters 
are frequently not included in the analysis data on the label. Therefore they have been calculated on the basis of the macro-composition of the mineral water. $\mathrm{The}_{25}$ has been calculated with the WATEQ4F program (Ball et al., 1991). For the mineral waters for which the measured $\mathrm{EC}_{25}$ is known as well, the measured values and the calculated values have been compared. These corresponded well (Figure 1).

According to Hem (1970) the TDS value can be calculated as $\mathrm{EC}_{25}(\mu \mathrm{S} / \mathrm{cm}) * \mathrm{~A}=\mathrm{TDS}(\mathrm{mg} / \mathrm{l})$. For any $\mathrm{EC}_{25}$ value the TDS can thus be calculated with an uncertainty of about $100 \mathrm{mg} / \mathrm{l}$. According to Hem (1970) the value of A varies between 0.55 and 0.75 . Based on the comparison between measured and calculated TDS, the value of 0.65 appeared to be the best fit for the mineral water data set.

\section{Water classification systems}

A selection of some existing water quality classification systems was used in order to characterize the different mineral water types.

EU mineral water directive

The criteria for the chemical composition of mineral water according to the EU mineral water directive are shown in Table 1. The criteria show a distinction based on total dissolved solids (TDS) and a further specification based on some characterizing cations and anions or carbon dioxide content

German curative mineral water classification

The common classification of the curative waters used in German health treatments originates from 1911 (Grünhut, 1911 and Begriffsbestimungen, 1991). According to this qualification a mineral water is designated as curative water when it contains at least $1.0 \mathrm{~g} / \mathrm{l}$ of dissolved minerals. A further specification is introduced on the basis of the characteristic compounds, of which the equivalent contribution must constitute at least $20 \%$ of the total dissolved compounds. Moreover, a further specification can be added on the basis of some characteristic elements that exceed a certain concentration limit. The following types are distinguished in this further specification:

- containing iron

- $\quad$ containing iodides

- containing sulphur

- containing radon more than $20 \mathrm{mg} / \mathrm{l} \mathrm{Fe} 2+$

more than $1 \mathrm{mg} / \mathrm{l} \mathrm{I-}$

more than $1 \mathrm{mg} / \mathrm{l} \mathrm{S}$

more than 666 Bq/1 Radon (Rn) (= 18 n Curie/l) 
- containing fluoride

- carbonated

- containing magnesium more than $1 \mathrm{mg} / \mathrm{l} \mathrm{F}$ -

more than $1 \mathrm{~g} / \mathrm{l}$ dissolved $\mathrm{CO}_{2}$

magnesium has an equivalent contribution of at least $20 \%$

Stuyfzand water classification

The Stuyfzand classification (Stuyfzand, 1986, 1993) subdivides the most important chemical water characteristics at 4 levels. The primary type is determined based on the chloride content (Table 6B). The type is determined on the basis of an index for hardness (Table 6C). The classification into subtypes is determined based on the dominant cations and anions. Finally, the class is determined on the basis of the sum of $\mathrm{Na}, \mathrm{K}$ and $\mathrm{Mg}$ in meq/l, corrected for a sea salt contribution.

Van Wirdum diagram

In the van Wirdum diagram (van Wirdum, 1991) analyses are classified based on the EC and ion ratio (IR). Three reference points are distinguished that are characteristic for the hydrological cycle: atmocline (rainwater), thalassocline (seawater) and lithocline water (calcium rich, fresh water). The ion ratio is calculated as follows: $\operatorname{IR}(\%)=100 * \frac{\left[1 / 2 \mathrm{Ca}^{2+}\right]}{\left[1 / 2 \mathrm{Ca}^{2+}\right]+\left[\mathrm{Cl}^{-}\right]} \quad(\mathrm{Ca}$ and $\mathrm{Cl}$ in meq/l $)$

Waters can be classified based on these ion ratios and it is also possible to calculate similarity coefficients on the basis of more chemical variables.

\section{Results}

\section{Macro-parameters and fluorine exceeding the drinking water standards}

Table 2 shows the WHO and Dutch drinking water standards. Table 3 shows that $10-20 \%$ of the mineral waters exceed the applied drinking water standards in terms of the concentration of calcium, magnesium, potassium, sodium, sulphate and fluorine. $4-9 \%$ of the mineral waters exceed the $\mathrm{Cl}$ standards. One third of the mineral waters do not meet the required minimum degree of hardness in the Dutch standards. The nitrate standard is not exceeded, but the nitrate target value is exceeded in three of the mineral waters, namely Spring Clear (England), Ein Gedi (Israel) and Appia (Italy). Among the countries represented by more than 10 different mineral waters 
(Germany, France, Italy, Spain and Belgium), the mineral waters from Germany exceed the standards most often. In $28-53 \%$ of the cases the Dutch standards for potassium, sodium, calcium, magnesium and sulphate are exceeded. The chloride standard is exceeded in $21 \%$ of the cases. A number of the French mineral waters also exceed the standards. In $19-32 \%$ of the cases the standards for potassium, sodium, magnesium and calcium are exceeded. Italy, Spain and Belgium exceed the standards considerably less often. $19 \%$ of the Italian mineral waters exceed the calcium standard, while virtually none of the Spanish and Belgian mineral waters exceed the standards. Figure 2 shows the percentage of times the standards were exceeded, subdivided into the 4 TDS classes based on the EU mineral water directive, including the $95 \%$ reliability interval. The figure shows that the number of times the standards are exceeded is related to the TDS value. The standards are hardly ever exceeded by mineral waters with a TDS lower than $500 \mathrm{mg} / \mathrm{l}$, while those in the classes $500-1500 \mathrm{mg} / \mathrm{l}$ and $>1500 \mathrm{mg} / \mathrm{l}$ TDS were more likely to exceed them.

\section{Mineral water types according to the $\mathrm{EU}$ mineral water directive}

Table 4 shows the classification in accordance with the EU mineral water directive. Most mineral waters are in the class 'low mineral concentration' (TDS 50-500 mg/l). The German mineral waters however primarily fall in the classes 'intermediate mineral concentration' (TDS 500-1500 mg/l) and 'high mineral concentration' (TDS > $1500 \mathrm{mg} / \mathrm{l})$. The further specification based on a number of characteristic compounds results in the designation of many of the mineral waters as containing both bicarbonate, sulphate, chloride, calcium, magnesium, fluoride as well as sodium. This is especially valid for the classes 'intermediate mineral concentration' and 'high mineral concentration'. These often include combinations of bicarbonate and calcium/magnesium, bicarbonate and sodium, sulphate and calcium/magnesium, or all of these taken together. The classes 'very low mineral concentration' and 'low mineral concentration' consist almost entirely of waters that can be designated as 'suitable for low sodium diets'.

\section{German curative water classification system}

According to the German classification of curative water described by Grünhut (1911) and Begriffsbestimungen (1991) the curative water designation applies to 66 (23\%) of the 291 mineral waters. This primarily involves mineral waters from Germany, France and Italy. The classification shows that the majority of the types of water is classified as $\mathrm{CaHCO}_{3}$ and $\mathrm{NaHCO}_{3}$ (Table 5). A smaller group consists of $\mathrm{CaSO}_{4}$ and $\mathrm{NaCl}$ types of water. Other types account for less than $10 \%$. Considering the classification based on characteristic elements, the types 
of water containing fluoride and magnesium regularly occur. Here too, the types of water overlap. A type of mineral water is seldom classified as one type only. On average, one mineral water brand can be classified into one to three different types, with peaks of up to six different types.

\section{Stuyfzand water classification}

As regards the subdivision into main types according to the Stuyfzand classification (Stuyfzand, 1986, 1993), 6 out of the 8 possible salt/fresh classes actually occur (Table $6 \mathrm{~b}$ ). The classes that occur most often are: oligohaline (42\%), fresh (29\%) and very oligohaline (21\%). The saltiest class that occurs is brackish-salt. The calculated hardnesses are very diverse too: 10 out of 11 classes actually occur. The majority (65\%) of the mineral waters is of the types moderately hard, hard and very hard. Like the German curative water classification system, which shows considerable resemblance to the Stuyfzand classification in terms of the division into subtypes, most mineral waters $(59 \%)$ are characterized as $\mathrm{CaHCO}_{3} .32 \%$ is characterized as one of the types

$\mathrm{NaHCO}_{3}, \mathrm{MgHCO}_{3}, \mathrm{CaSO}_{4}$ or $\mathrm{NaCl}$. The results of the Stuyfzand classification indicate that the dissolution of calcium is an important process in most of the mineral waters. Moreover, the chemical composition of a lot of mineral waters refers to an origin in dolomite or gypsum types of rock. The $\mathrm{NaCl}$ waters indicate a relationship with seawater. $\mathrm{NaHCO}_{3}$ is probably a transitional type between fresh and salt water, influenced by cation exchange with the soil adsorption complex. A majority of the mineral waters (79\%) shows a composition that is indicative of a fresh water intrusion according to the Stuyfzand classification. In $15 \%$ of the cases there is a balance. Types of water that are indicative for a saltwater intrusion do not occur.

\section{Van Wirdum diagram}

The results of the van Wirdum diagram show that the de mineral waters are rather equally distributed over the three reference samples from the hydrological cycle. However, the emphasis is on lithocline (calcium-rich, fresh) water. There also are mineral waters that are characterized as atmocline (rain water). Moreover, the composition of a number of mineral waters suggests a similarity to seawater. This classification also shows that the subdivision based on hardness and on fresh/salt classes is an important distinctive criterion. Figure 3 shows a comparison between the van Wirdum diagram and the Stuyfzand classification. The fresh/salt subdivision using the Stuyfzand method can easily be recognized: the oligohaline waters ( $\mathrm{G}$ and $\mathrm{g}$ ) are in the zone lithoclineatmoclien water and the fresh-brackish (f), the brackish (B) and the salt-brackish (b) classes in the transitional area between lithocline and thalassocline water. The Stuyfzand hardness classes can also be found in groups, 
ascending from atmocline to thalassocline water. The largest group of mineral waters according to Stuyfzand $\left(\mathrm{CaHCO}_{3}\right)$ is found as expected around the lithocline type of water in the van Wirdum system. This also applies to the $\mathrm{MgHCO}_{3}$ and $\mathrm{CaSO}_{4}$ waters. According to the van Wirdum diagram the $\mathrm{NaCl}$ waters not only indicate seawater influence, since these are not only found in the thalassocline zone but in the atmocline-thalassocline zone as well. In agreement with the conclusion based on Stuyfzand, the $\mathrm{NaHCO}_{3}$ waters are situated in the transitional area to thalassocline water.

\section{Proposed mineral water type classification}

The various water classification systems indicate that the total amount of dissolved compounds, the chloride content (fresh/salt) and the hardness are the primary distinctive criteria. A subdivision into various types of mineral water with the objective of offering consumers a simple tool for assessing the differences between mineral waters should therefore include these elements. Therefore, in order to conform as much as possible to the existing water classification systems, the following subdivision is proposed (Table 6). As far as hardness is concerned, the classification based on the Stuyfzand system is applied. This is based on a calculation of the hardness on the basis of calcium and magnesium. Based on this subdivision 4 main groups can be distinguished. As expected, the hardness and the salt content increase with increasing mineral concentration in the water.

\section{Comparison with Dutch tap water}

Table 7 shows the classification based on the system described above for the Dutch and the Belgian mineral waters as well as for a number of typical foreign mineral waters. The table also indicates an approximate price per litre in Dutch stores. The table shows that in terms of the parameters involved, Dutch tap water shows considerable resemblance to the average Dutch and Belgian mineral waters. The chloride content of the tap water is somewhat higher. This is related to the fact that part of the Dutch drinking water is collected from surface (Rhine) water. The similarity between tap water and mineral water does not extend to the price. On average, Dutch tap water is about 500 times cheaper. For reasons of comparison a number of other European mineral waters are also presented. These are often harder and contain a larger quantity of dissolved compounds. Figure 4 shows the mineral waters per European country in a van Wirdum diagram. This shows that the majority of the mineral waters is of the lithocline, calcium-rich type of water. In terms of these parameters Dutch tap water is average and not very calcium-rich. Like the Spanish mineral waters, the Dutch and the Belgian mineral waters fall in the types atmocline-lithocline, whereas the German mineral waters are generally much saltier and 
primarily fall in the lithocline-thalassocline zone. The French mineral waters are very diverse, whereas the Italian, Austrian and Swiss mineral waters are primarily of the lithocline type.

\section{Conclusion}

Out of a dataset of 291 mineral water brands, 9-20\% of the mineral waters studied exceeded the Dutch drinking water standards for chloride, calcium, magnesium, potassium, sodium, sulphate and fluorine. Among the countries represented by more than 10 different mineral waters (Germany, France, Italy, Spain and Belgium), the German mineral waters exceeded the standards most often. The standards are hardly ever exceeded in mineral waters with a TDS lower than $500 \mathrm{mg} / \mathrm{l}$, but more frequently by mineral waters in the classes TDS 500-1500 $\mathrm{mg} / \mathrm{l}$ and TDS $>1500 \mathrm{mg} / \mathrm{l}$. The various classification systems show that a majority of the mineral waters can be characterized as calcium-rich, fresh water. For the mineral water data set the amount of dissolved compounds, the hardness and the chloride content appear to be the most important distinguishing criteria. Therefore, a classification is suggested that is based on these criteria and fits in with existing water classification systems. This will offer consumers a tool for assessing the mineral water on the basis of the chemical composition data on the bottle label.

\section{Acknowledgements}

The collection of mineral waters that is presented in this paper came about with the help of many friends and formal colleagues from The Netherlands Institute of Applied Geoscience TNO-NITG and the Physical geography department at Utrecht University. I would like to thank Geert van Wirdum for his comments on a preliminary version.

\section{Appendice drinking water standards}

According to the WHO (1993) no standards have been established for TDS, chloride, sodium, potassium, hardness and sulphate that are based on health effects. The standards that have been established are based on undesirable taste effects. Moreover, increased concentration of these compounds will often lead to corrosion of water pipes or to scale deposits. The nitrate standard is based on health effects. This also applies to the fluorine standard, but it is mentioned that depending on local climatological conditions and the amount of water consumed, it is sometimes difficult to meet this standard. The chloride standard is primarily based on the 
undesirable taste effect at concentration higher than about $250 \mathrm{mg} / \mathrm{l}$. However, people may get used to drinking water with chloride concentration higher than $250 \mathrm{mg} / \mathrm{l}$ and concentration up to $600 \mathrm{mg} / \mathrm{l}$ can be considered safe. Very high chloride concentration lead to an increased risk of corrosion of the metals in the distribution system, which also depends on the hardness of the water. This may result in increased concentration of metals in the drinking water. In terms of sodium it can be said that there may be a relation between sodium in drinking water and the occurrence of high blood pressure. However, no firm conclusions can be drawn about this. Therefore the sodium standard is only based on negative taste effects. These occur at concentration higher than $200 \mathrm{mg} / \mathrm{l}$. No data are available on the possible health effects of the TDS content. But TDS may strongly influence the taste of drinking water. Water with a TDS lower than $1000 \mathrm{mg} / \mathrm{l}$ is usually acceptable for consumers, although this may strongly depend on local conditions. A higher TDS may lead to extreme scale deposits in pipelines, boilers and home appliances. Water with a low TDS tastes flat and is often considered to be tasteless. There are indications that extremely soft water adversely affects the mineral balance. However, no detailed studies are available for evaluation. The public acceptance of the hardness of the water strongly depends on the local conditions. The taste limit for calcium is somewhere in between 100-300 mg/l and for magnesium it is probably lower. In some cases a hardness of $500 \mathrm{mg} / \mathrm{l}$ is tolerated by consumers. Depending on factors such as $\mathrm{pH}$ and alkalinity, a hardness of more than about $200 \mathrm{mg} / \mathrm{l}$ will lead to scale deposits in the piping system. On the other hand soft water, with a hardness of less than $100 \mathrm{mg} / \mathrm{l}$, may cause corrosion in the piping system. Sulphate is one of the least toxic anions. However, the presence of high concentration in the drinking water may lead to dehydration, stomach complaints and diarrhoea. Therefore authorities are advised to be alert in case of water with sulphate concentration higher than $500 \mathrm{mg} / \mathrm{l}$. Moreover, sulphate has a clear taste effect, which varies between $250 \mathrm{mg} / \mathrm{l}$ for sodium sulphate and $1000 \mathrm{mg} / \mathrm{l}$ for calcium sulphate. In general the adverse affect on the taste is said to be minimal at levels lower than $250 \mathrm{mg} / \mathrm{l}$. The $50 \mathrm{mg} / \mathrm{l}$ standard for nitrate is based on health effects. The WHO standard for fluorine of $1.5 \mathrm{mg} / \mathrm{l}$ is also based on health effects. Higher concentration increase the chance of skeletal deformations (fluorosis).

\section{References}

Ball JW, Nordstrom DK (1991) WATEQ4F - User's manual for WATEQ4F. U.S. Geological Survey Open-File Report 91-183

Begriffsbestimungen für Kurorte, Erholungsorte und Heilbrunnen (1991) Hrsg.v. Deutschen Bäderverband e.V. und vom Deutschen Fremdenverkehrsverband e.V. Bonn-Frankfurt/Main 
Fricke M (1993) Natural mineral water, curative-medical waters and their protection. Environmental Geology 22 (1993): 153-161

Grünhut, L (1911) Z. Balneologie 4: 433-470, zit.n. Quentin (1962)

Hem J D (1970) Study and Interpretation of the Chemical Characteristics of Natural Water. Second Edition Geological Survey Water Supply Paper 1473 - United States Government Printing Office. Washington

Stuyfzand P J (1986) A new hydrochemical classification of watertypes, with Dutch examples of application. $\mathrm{H}_{2} \mathrm{O}$ (19) 1986 number 23 (in Dutch)

Stuyfzand P J(1993) Hydrochemistry and hydrology of the coastal dune area of the western Netherlands. KIWA N.V. Research aand Consultancy Division. Nieuwegein, The Netherlands

Wirdum G van (1991) Vegetation and hydrology of floating rich-fens. Datawyse Maastricht 310 p.

World Health Organization (1993) Guidelines for drinking-water quality. Geneva

Zuurdeeg, BW, Weiden, MJJ van der (1985) Geochemical aspects of European bottled water. In: Geothermics thermal - mineral waters and hydrolgeology. Theophrastus publications S.A Athens 
Table 1 Criteria for mineral waters in accordance with the EU mineral water directive

\begin{tabular}{ll}
\hline Mineral water type & Criterion \\
\hline $\begin{array}{l}\text { Very low mineral concentration } \\
\text { Low mineral concentration }\end{array}$ & Mineral content $(\mathrm{TDS})<50 \mathrm{mg} / \mathrm{l}$ \\
Intermediate mineral concentration & TDS $50-500 \mathrm{mg} / \mathrm{l}$ \\
High mineral concentration & TDS $500-1500 \mathrm{mg} / 1$ \\
& TDS $>1500 \mathrm{mg} / 1$ \\
Containing bicarbonate & Bicarbonate $>600 \mathrm{mg} / 1$ \\
Containing sulphate & Sulphate $>200 \mathrm{mg} / 1$ \\
Containing chloride & Chloride $>200 \mathrm{mg} / 1$ \\
Containing calcium & Calcium $>150 \mathrm{mg} / 1$ \\
Containing magnesium & Magnesium $>50 \mathrm{mg} / 1$ \\
Containing fluoride & Fluoride $>1 \mathrm{mg} / 1$ \\
Containing iron & Bivalent iron $>1 \mathrm{mg} / 1$ \\
Acid & Carbon dioxide $>250 \mathrm{mg} / 1$ \\
Containing sodium & Sodium $>200 \mathrm{mg} / 1$ \\
Suitable for low sodium diets & Sodium $<20 \mathrm{mg} / 1$ \\
\hline
\end{tabular}

Table 2 WHO and Dutch drinking water standards

\begin{tabular}{|l|l|l|l|l|l|l|l|l|l|}
\hline $\begin{array}{l}\text { Drinking water standards } \\
(\mathrm{mg} / \mathrm{l})\end{array}$ & $\mathrm{Cl}$ & $\mathrm{Ca}$ & $\mathrm{Mg}$ & $\begin{array}{l}\mathrm{Ca}+\mathrm{Mg} \\
\mathrm{min} .\end{array}$ & $\mathrm{K}$ & $\mathrm{Na}$ & $\mathrm{NO}_{3}$ & $\mathrm{SO}_{4}$ & $\mathrm{~F}$ \\
\hline WHO & 300 & - & 50 & - & - & 175 & 50 & 250 & 1.5 \\
\hline Netherlands & $150^{*}$ & $150^{*}$ & $50^{* 1}$ & $60^{* 2}$ & $12^{* 1}$ & $120^{* 1}$ & $50^{* 1} / 25^{* 3}$ & $150^{* 1}$ & $1.1^{*}$ \\
\hline
\end{tabular}

* may only be exceeded in circumstances out of the waterworks' control

*1 may only be exceeded if the responsible minister grants dispensation

$* 2$ this value may not be lower (calculated as $\mathrm{Ca}+1.66 \mathrm{Mg}(\mathrm{mg} / \mathrm{l})$ )

*3 target value based on $4^{\text {th }}$ Dutch memorandum on water management

Table 3. Number of times drinking water standards are exceeded

\begin{tabular}{|l|l|l|l|l|l|l|l|l|l|}
\hline $\begin{array}{l}\text { Times the standard is } \\
\text { exceeded (\% of total data set) }\end{array}$ & $\mathrm{Cl}$ & $\mathrm{Ca}$ & $\mathrm{Mg}$ & $\begin{array}{l}\mathrm{Ca}+\mathrm{Mg} \\
\text { min. }\end{array}$ & $\mathrm{K}$ & $\mathrm{Na}$ & $\mathrm{NO}_{3}$ & $\mathrm{SO}_{4}$ & $\mathrm{~F}$ \\
\hline WHO & 4 & - & 16 & - & - & 16 & 0 & 11 & 10 \\
\hline Netherlands & 9 & 16 & 16 & 33 & 19 & 20 & $0 / 1$ & 14 & 17 \\
\hline
\end{tabular}

Table 4 Percentage of mineral waters in the various classes in accordance with the EU mineral water directive

\begin{tabular}{ll}
\hline Class & Percentage \\
\hline Very low mineral concentration & $4 \%$ \\
Low mineral concentration & $60 \%$ \\
Intermediate mineral concentration & $24 \%$ \\
High mineral concentration & $12 \%$ \\
& \\
Containing bicarbonate & $20 \%$ \\
Containing sulphate & $12 \%$ \\
Containing chloride & $8 \%$ \\
Containing calcium & $16 \%$ \\
Containing magnesium & $16 \%$ \\
Containing fluoride & $6 \%$ \\
Containing sodium & $15 \%$ \\
Suitable for low sodium diets & $55 \%$ \\
\hline
\end{tabular}


Table 5 Percentage of mineral waters in the various classes in accordance with the German curative water classification system

\begin{tabular}{|l|lr|lr|ll|l|}
\hline & $\mathrm{Na}$ & $\mathrm{Ca}$ & \multicolumn{3}{l|}{$\mathrm{Mg}$} \\
\hline $\mathrm{HCO}_{3}$ & $\mathrm{NaHCO}_{3}$ & $67 \%$ & \multicolumn{4}{|l|}{$\mathrm{CaMgHCO}_{3}$} & $68 \%$ \\
\hline $\mathrm{SO}_{4}$ & $\mathrm{NaSO}_{4}$ & $3 \%$ & $\mathrm{CaSO}_{4}$ & $26 \%$ & $\mathrm{MgSO}_{4}$ & $3 \%$ \\
\hline $\mathrm{Cl}$ & $\mathrm{NaCl}$ & $17 \%$ & $\mathrm{CaCl}$ & $8 \%$ & - & \\
\hline
\end{tabular}

Table $6 \quad$ Classification system for mineral waters

\begin{tabular}{lccc}
$\mathrm{A}$ & & & \\
\hline Dissolved compounds & Code & $\mathrm{TDS}(\mathrm{mg} / \mathrm{l})$ & $\mathrm{EC}_{25}(\mu \mathrm{S} / \mathrm{cm})$ \\
\hline Very low mineral concentration & TDS 1 & $<50$ & $<77$ \\
Low mineral concentration & TDS 2 & $50-500$ & $77-769$ \\
Intermediate mineral concentration & TDS 3 & $500-1500$ & $769-2308$ \\
High mineral concentration & TDS 4 & $>1500$ & $>2308$ \\
\hline
\end{tabular}

\section{B}

\begin{tabular}{lcl}
\hline Fresh-Salt class & Code & Chloride $(\mathrm{mg} / \mathrm{l})$ \\
\hline Very oligohaline & $\mathrm{G}$ & $<5$ \\
Oligohaline & $\mathrm{g}$ & $5-30$ \\
Fresh & $\mathrm{F}$ & $30-150$ \\
Fresh-brackish & f & $150-300$ \\
Brackish & B & $300-1000$ \\
Brackish-salt & b & $1000-10,000$ \\
\hline
\end{tabular}

\begin{tabular}{lcl}
\hline C & & \\
\hline Hardness & Code & $\begin{array}{l}\text { Hardness } \\
(\mathrm{Ca}+\mathrm{Mg} \text { in meq/l) }\end{array}$ \\
\hline Very soft & $*$ & $0-0.5$ \\
Soft & 0 & $0.5-1$ \\
Moderately hard & 1 & $1-2$ \\
Hard & 2 & $2-4$ \\
Very hard & 3 & $4-8$ \\
Extremely hard & 4 & $8-16$ \\
Extremely hard & 5 & $16-32$ \\
Extremely hard & 6 & $32-64$ \\
Extremely hard & 7 & $64-128$ \\
Extremely hard & 8 & $128-256$ \\
Extremely hard & 9 & $>256$ \\
\hline
\end{tabular}

D: The 4 main groups distinguished and the water types occurring in the mineral water data set.

\begin{tabular}{lllll}
\hline Dissolved compounds & Fresh-salt classes & Hardness \\
\hline Very low mineral concentration & $\mathrm{G}, \mathrm{g}$ & (very) oligohaline & $*-0$ & (very) soft \\
Low mineral concentration & $\mathrm{G}, \mathrm{g}, \mathrm{F}$ & (very) oligohaline - fresh & $*-4$ & (very) soft - extremely hard \\
Intermediate mineral concentration & $\mathrm{G}, \mathrm{g}, \mathrm{F}, \mathrm{f}, \mathrm{B}$ & (very) oligohaline - brackish & $*, 2-6$ & (very) soft - extremely hard \\
high mineral concentration & $\mathrm{G}, \mathrm{F}, \mathrm{f}, \mathrm{B}, \mathrm{b}$ & oligohaline - brackish/salt & $2-9$ & (extremely) hard \\
\hline
\end{tabular}


Table 7 Classification of Dutch tap water and a number of popular mineral waters in the Netherlands

\begin{tabular}{|c|c|c|c|c|c|}
\hline Water & Country & $\begin{array}{c}\text { Dissolved } \\
\text { compounds }\end{array}$ & Fresh-salt & Hardness & $\begin{array}{c}\text { Price } \\
\text { Euro per liter }\end{array}$ \\
\hline Dutch tapwater *1 & Netherlands & low & fresh & hard & 0,00009 \\
\hline Ciseau & Netherlands & low & very oligohaline & very hard & - \\
\hline Oerwater & Netherlands & low & oligohaline & moderately hard & - \\
\hline Prise d'Eau & Netherlands & low & oligohaline & hard & - \\
\hline Sourcy & Netherlands & low & oligohaline & hard & 0,39 \\
\hline Hébron & Netherlands & low & oligohaline & very hard & 0,23 \\
\hline Bar le Duc & Netherlands & low & oligohaline & very hard & 0,29 \\
\hline Aqua Viva & Netherlands & low & oligohaline & very soft & 0,27 \\
\hline Léberg & Netherlands & low & fresh & very hard & - \\
\hline Spa Blauw & Belgium & very low & very oligohaline & very soft & 0,38 \\
\hline Spa Rood & Belgium & very low & oligohaline & very soft & 0,41 \\
\hline Bru & Belgium & low & very oligohaline & hard & 0,88 \\
\hline Valvert & Belgium & low & very oligohaline & hard & - \\
\hline Spontin & Belgium & low & oligohaline & hard & - \\
\hline Presby & Belgium & low & oligohaline & very hard & - \\
\hline Val d'Aisne & Belgium & low & oligohaline & very hard & - \\
\hline Val & Belgium & low & fresh & very soft & - \\
\hline Chaudfontaine & Belgium & low & fresh & very hard & 0,38 \\
\hline Ordal & Belgium & low & fresh & very hard & - \\
\hline Reina & Belgium & low & fresh & very hard & - \\
\hline Sty & Belgium & low & fresh & very hard & - \\
\hline TOP Souveraine & Belgium & intermediate & fresh & very soft & - \\
\hline Mont Roucous & France & very low & very oligohaline & very soft & 0,88 \\
\hline San Pellegrino & Italy & low & very oligohaline & hard & 1,39 \\
\hline Evian & France & low & very oligohaline & very hard & 0,75 \\
\hline Volvic & France & low & oligalien & moderately hard & - \\
\hline Ty Nant & England & low & oligalien & hard & 3,40 \\
\hline Perrier & France & low & fresh & very hard & 0,93 \\
\hline Contrex & France & intermediate & oligalien & extremely hard & 0,83 \\
\hline Badoit & France & intermediate & fresh & extremely hard & - \\
\hline Christinen & Germany & intermediate & brak & moderately hard & - \\
\hline Rogaska Donat & Slovenia & high & fresh & extremely hard & 1,59 \\
\hline Vichy & France & high & fresh-brackisch & very hard & - \\
\hline
\end{tabular}

*1 average of 30 tap points 


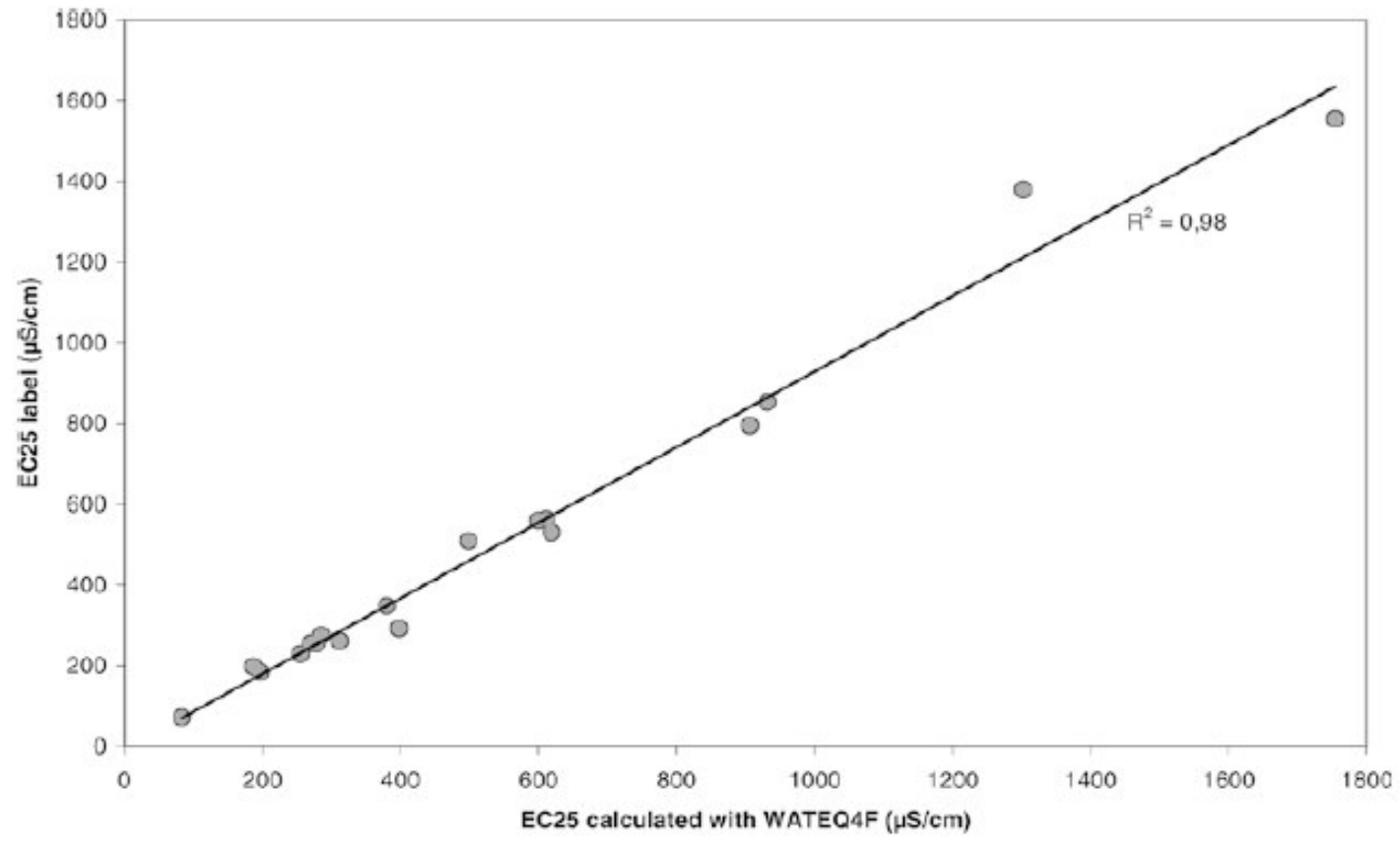

Figure 1 Comparison of calculated and measured $\mathrm{EC}_{25}$ on mineral water label 

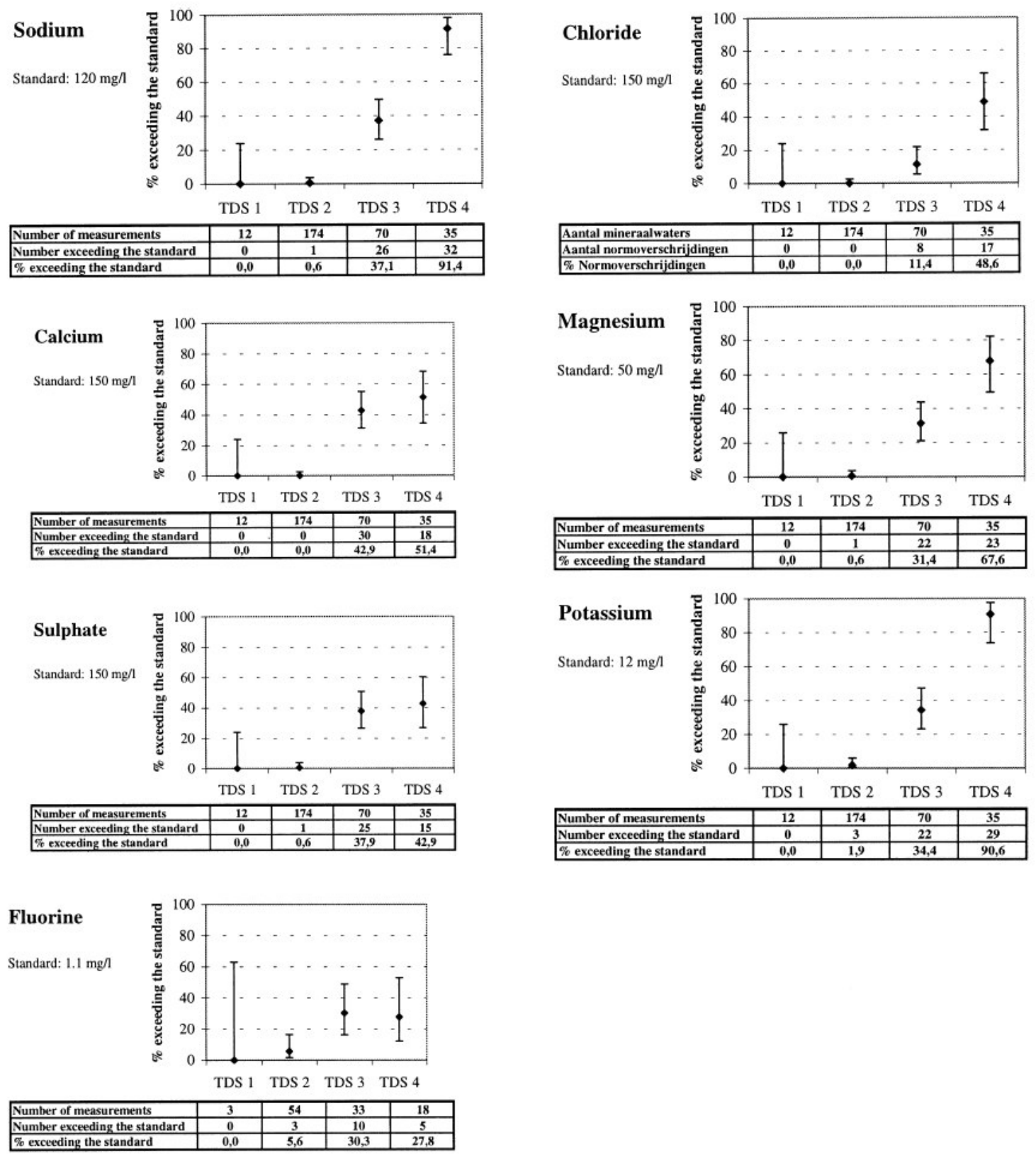

Figure 2 Calculated number of times the Dutch drinking water standards are exceeded (Water supply systems decree, 1984) with $95 \%$ reliability interval, subdivided into TDS contents in accordance with the EU mineral water directive $(\mathrm{mg} / \mathrm{l})$.
TDS $1<50 \mathrm{mg} / 1$
very low mineral concentration
TDS2 $50-500 \mathrm{mg} / \mathrm{l}$
low mineral concentration
TDS3 $500-1500 \mathrm{mg} / \mathrm{l}$
intermediate mineral concentration
TDS4 >1500 mg/l
high mineral concentration 


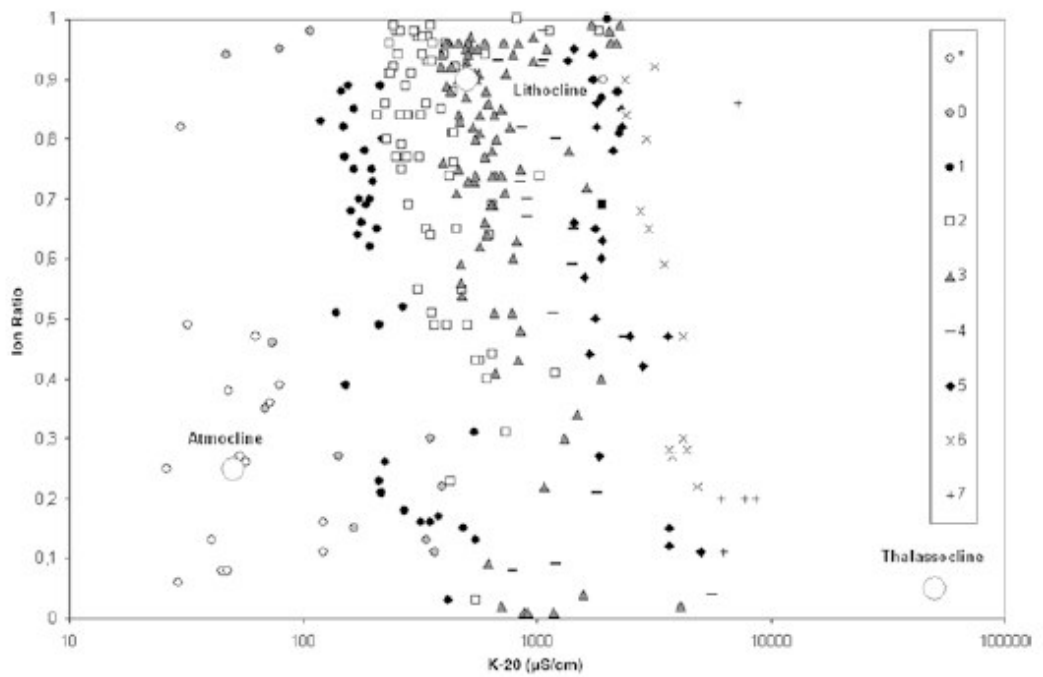

Figure 3 Comparison of the van Wirdum diagram and Stuyfzand water classification with regard to hardness, fresh-salt classes and dominant cation / anion
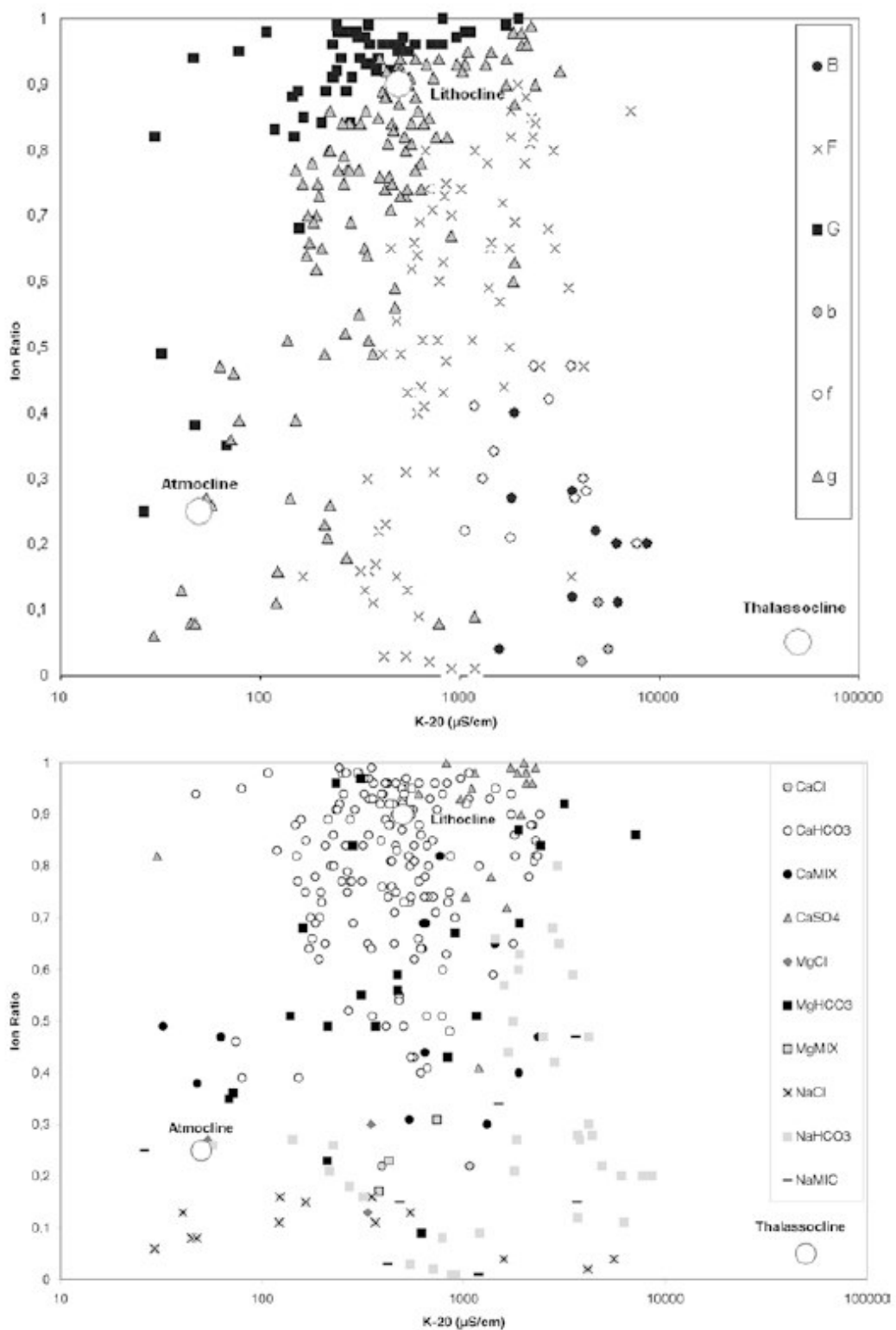


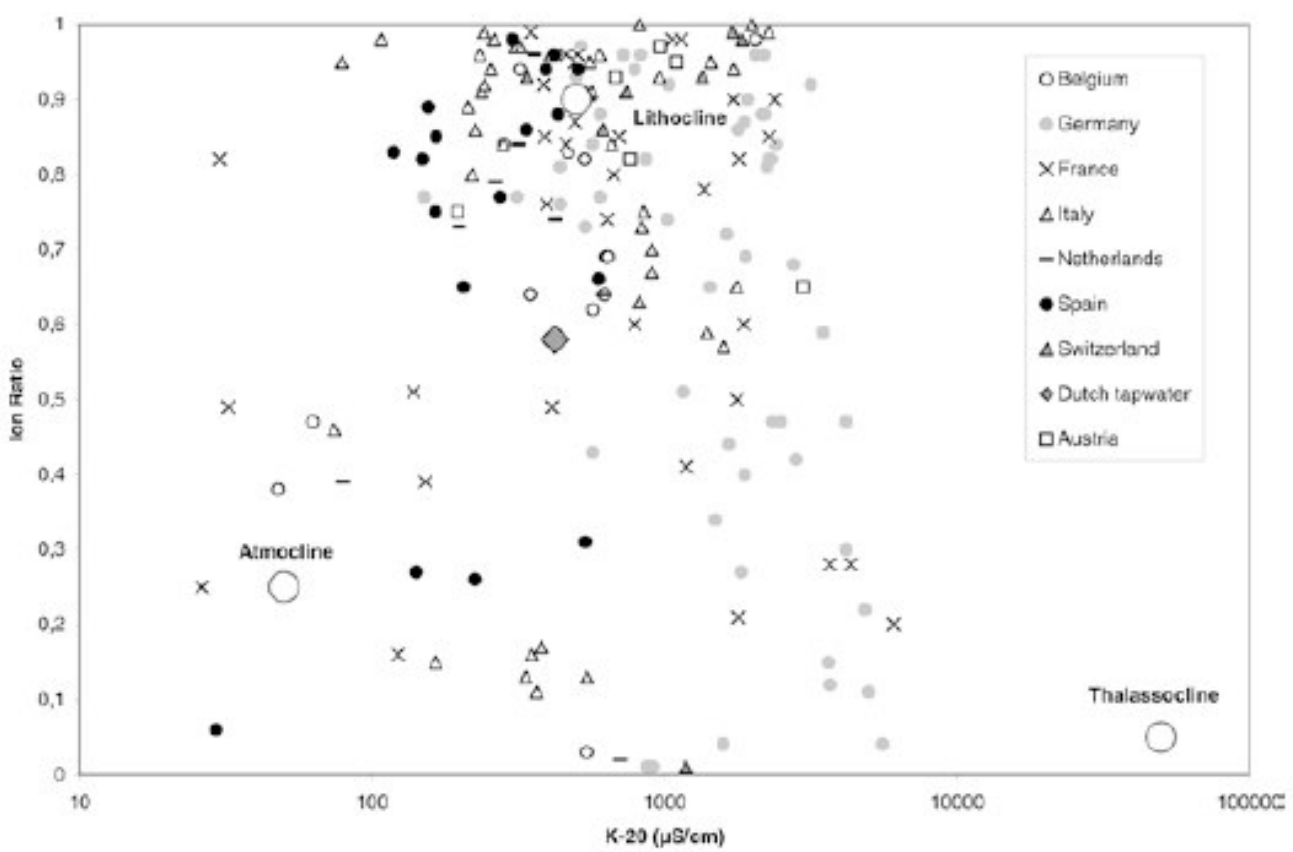

Figure 4 Van Wirdum diagram for European mineral waters, indicated per country 